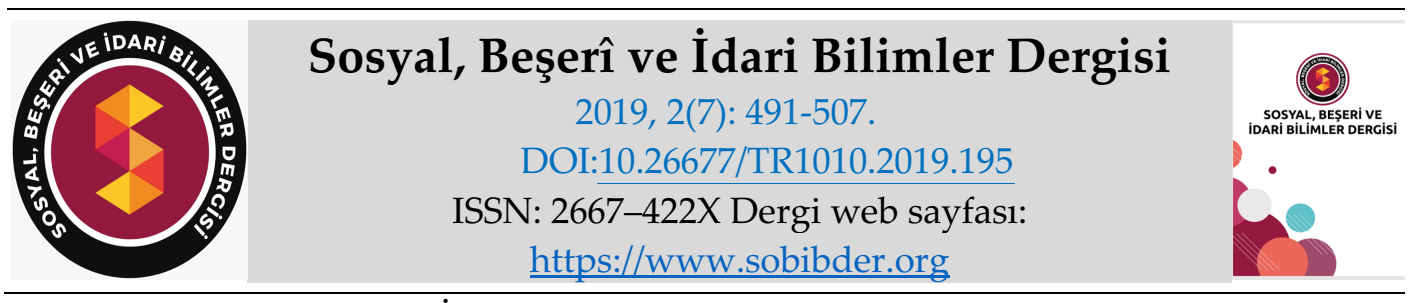

ARAŞTIRMA MAKALESI

\title{
Lisans Düzeyinde Turizm Eğitimi Alan Öğrencilerin Eğitim Öncesinde ve Eğitim Sürecinde Sektöre İlişkin Algıları*
}

Arş. Gör. Engin TENGİLIMOĞLU, Selçuk Üniversitesi, Beyşehir Ali Akkanat Turizm Fakültesi, Konya, e-posta: entengilimoglu@selcuk.edu.tr

ORCID: https://orcid.org/0000-0001-7080-6147

Öz

Literatürde üniversite düzeyinde turizm eğitimi alan öğrencilerin turizm sektörüne karşı olumsuz algı ve tutum içerisinde oldukları ve bundan dolayı turizm sektöründe eğitimli istihdamın sınırlı sayıda kaldığı belirtilmektedir. Bu bulgudan yola çıkarak bu çalışmada lisans düzeyinde turizm eğitimine başlayan öğrencilerin eğitim öncesi ve eğitim sürecinde turizm sektörüne ilişkin algıları, oluşturulan anket yardımı ile ölçülerek karşılaştırılmıştır. İki yılı kapsayan çalışmaya 2016 yılında Selçuk Üniversitesi, B. A. A. Turizm Fakültesi, Turizm işletmeciliği bölümüne kayıt yaptıran 73 öğrenci katılmıştır. 2018 yılı haziran ayında yapılan ikinci ankette ise 73 öğrenciden öğrenimine devam eden 43'üne ulaşılabilmiştir. Elde edilen verilere eşleştirilmiş örneklerde t-testi analizi uygulanarak öğrencilerin eğitim öncesi ve eğitim süreci algıları karşılaştırılmıştır. Sonuç olarak aynı öğrenci grubunun eğitime başlamadan önce turizm sektörüne karşı daha olumlu bir bakış açısına sahip olduğu ve bu olumlu algının yerini zamanla olumsuz düşüncelere bıraktığı tespit edilmiştir. Ayrıca öğrencilerin eğitim aldığı iki yıllık süreçte iş deneyimlerinin ortalama 2 ay arttığı görülmüştür.

* Bu çalışma 17-21 Ekim 2018 tarihinde 19. Ulusal Turizm Kongresinde sunulan “Lisans Düzeyinde Turizm Eğitimi Alan Öğrencilerin Eğitim Öncesinde ve Eğitim Sürecinde Sektöre İlişkin Algıları” isimli bildirinin genişletilmiş halidir.

Anahtar Kelimeler: Turizm Eğitimi, Öğrencilerin Sektör Algıları.

Makale Gönderme Tarihi: 08.04.2019

Makale Kabul Tarihi: 23.07.2019

Önerilen Atıf:

Tengilimoğlu, E. (2019). Lisans Düzeyinde Turizm Eğitimi Alan Öğrencilerin Eğitim Öncesinde ve Eğitim Sürecinde Sektöre İlişkin Algıları, Sosyal, Beşeri ve İdari Bilimler Dergisi, 2(7): 491-507.

(c) 2019 Sosyal, Beşerî ve İdari Bilimler Dergisi. 


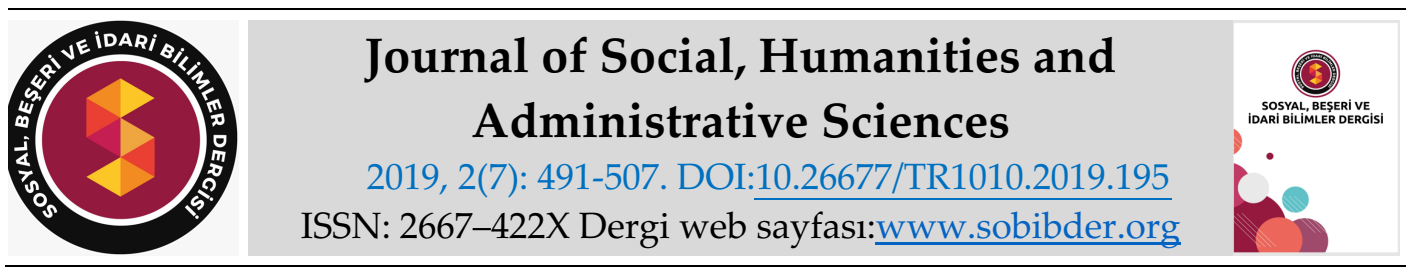

\title{
RESEARCH PAPER
}

\section{Comparing the Students Perceptions Towards Tourism Sector Before and During Education Process}

Research Assistant Engin TENGİLIMOĞLU, Selçuk University, Beyşehir Ali Akkanat Faculty of Tourism, Konya, e-mail: entengilimoglu@selcuk.edu.tr

ORCID: https://orcid.org/0000-0001-7080-6147

\begin{abstract}
In the relevant literature it claims that the students who get tourism education at university have negative perception and attitude towards the tourism sector and hence there are inadequate educated staff in the tourism sector. Based on this finding, in this study tourism management students' perceptions of the tourism sector were compared by measuring with literature-based questionnaire in the Pre-education and during education process. Questionnaire applied 73 students enrolled tourism management department in 2016 and in 2018 only 43 of 73 students can be reached. By using Paired Sample t-test, students' perceptions of tourism sector before education and during education process was compared. As a result, it has been determined that the same students have positive perceptions towards tourism sector before starting education and this positive perception has been replaced by negative thoughts during education process. Moreover, the students have gained average 2 months experience in these two-year education process.
\end{abstract}

Keywords: Tourism Education, Students Perception of Tourism Sector

Received: 08.04.2019

Accepted: 23.07.2019

\section{Suggested Citation:}

Tengilimoğlu, E. (2019). Comparing the Students Perceptions Towards Tourism Sector Before and During Education Process, Journal of Social, Humanities and Administrative Sciences, 2(7): 491-507.

(C) 2019 Sosyal, Beşerî ve İdari Bilimler Dergisi. 


\section{GİRIŞ}

Turizm sektörüne ilişkin göstergeler incelendiğinde 1950 yılında turizm hareketlerine katılan dünya genelinde 25 milyon kişi varken 1980'e gelindiğinde bu rakamın 278 milyona ulaşttğg ve günümüzde ise 1 milyar 235 milyonun üzerine çıktığı bilinmektedir. Dünya Turizm Örgütü'nün (UNWTO) tahminlerine göre yıllık ortalama \%3,9 artışla turizm hareketlerine katılan kişi sayısının 2030 yılına kadar 1 milyar 800 milyona ulaşması beklenmektedir. Artan turist sayılarına paralel olarak turizm gelirlerinin de küresel bazda 1950 yılı için 2 milyar dolardan sırasıyla 1980 yılında 104 milyar dolara ve günümüzde ise 1 trilyon 220 milyar dolara ulaştığı görülmektedir. UNWTO verilerine göre geçtiğimiz 60 yıl boyunca çeşitlenmeye ve yayılmaya devam eden turizm sektörü hızlı büyüme oranlarıyla kısa sürede dünyanın en büyük sektörlerinden biri haline gelmiştir. Öyle ki turizm sektörü dünya ihracat sıralamasında petrol ürünleri ve kimyasallardan sonra üçüncü sırada yer almaktadır (UNWTO, 2017:2).

Yukarıda ifade edilen bu gelişmeler dünya genelinde turizm sektörünün ulaştığı noktayı ve buna bağlı olarak ülkelerin turizme karşı göstermiş olduğu teveccühü anlamak açısından önemlidir. Dünya genelinde turizm sektörüne dönük yaşanan bu gelişmeler neticesinde ortaya çıkan pasta ülkelerin iştahını kabartmakta ve turizm sektörüne karşı duyulan ilgiyi arttırarak rekabetin kızışmasına neden olmaktadır. Ülkeler turizm sektöründe rekabet avantajı elde etmek adına yaptıkları alt-üst yapı yatırımlarının yanı sıra hizmet kalitesini arttırarak (Duman vd., 2006:51) rekabet avantajının sürdürülebilirliğine katkı sağlayacak olan turizm eğitimine de (Tuna vd., 2018:42) önem vermektedirler.

Literatürde artan rekabetle birlikte turizm sektöründe var olmanın müşteri memnuniyetini sağlamakla (Ünlüönen vd., 2010:145) müşteri memnuniyetinin ise hizmet kalitesi ile (Aymankuy ve Aymankuy, 2013:2) hizmet kalitesinin de turizm eğitimi ile (Ünlüönen ve Boylu, 2005:13) mümkün olabileceği belirtilmektedir. Bu bağlamda turizm eğitimi almış kişilerin sektörde çalışması (Kuşluvan ve Kuşluvan, 2000:252; Pelit ve Güçer, 2006:143; Işık vd., 2018:12) turizm sektöründe başarının sağlanması açısından önemli bir konu haline gelmektedir.

$\mathrm{Bu}$ çalışmada konu ile ilgili yazın incelemesi yapılarak turizm öğrencilerinin sektöre ilişkin algılarını ölçmek için bir anket formu oluşturulmuştur. Daha sonra oluşturulan anket formu ile lisans düzeyinde turizm eğitimi alan öğrencilerin eğitimlerine başlamadan önceki (kayıt esnasında) turizm sektörü algılarıyla 2. sınıfın sonunda oluşan turizm sektör algıları karşılaştırılarak eğitim sürecinde öğrencilerin algılarında ortaya çıkan değişimin nedenleri incelenmiştir. Uygulanan anketler numaralandırılmış ve iki yıl sonra uygulanan anketlerle eşleştirilerek aynı öğrencilerin daha önce doldurmuş oldukları anket formları ile birleştirilmiştir.

\section{LİTERATÜR}

Dünya Seyahat ve Turizm Konseyi (WTTC) tarafından her yıl yayınlanan Seyahat ve Turizm Ekonomik Etki Raporunda turizm sektörünün doğrudan, dolaylı ve uyarılmış etkileriyle birlikte dünya ticaret hacminin 2017 yılında \%10,4'ünü oluşturduğu belirtilmektedir ve yapılan tahminlerde bu oranın yıllık ortalama \%3,8 artışla 2028 yılında \%11,7'ye ulaşması öngörülmektedir. Aynı raporda turizm sektörünün küresel anlamda toplam istihdamın \%9,9' unu oluşturduğu ve bu rakamında yıllık ortalama \%2,5 artışla 2028 yılında \%11,6'ya ulaşacağ tahmin 
edilmektedir (WTTC, 2018a:1). Bu istatistikler kapsamında dünya genelindeki her 10 işten birinin turizm sektörü ile ilişkili olduğu bilinmektedir.

Özellikle gelişmekte olan ülkelerin turizm pazarındaki paylarının 1980 yılında \%30'dan günümüze yaklaşı $\% 45$ 'e çıkması ve 2030 yılı itibari ile bu payın \%57'ye ulaşması yönündeki tahminler (UNWTO, 2017:3) gelişmekte olan ülkelerin turizm sektörüne duyduğu ilginin göstergesini ifade etmektedir. Gelişmekte olan ülkeler statüsünde bulunan Türkiye açısından turizm olayı ele alındığında ülkenin toplam ihracatının \%14'ünü turizm sektörünün oluşturduğu görülmektedir. WTTC (2018b:1) tarafından yapılan tahminlerde bu oranın her yıl ortalama \%4,4 artışla 2028 yılında \%20,7'ye ulaşması beklenmektedir. Buna ek olarak turizm sektörünün toplam istihdamın \%7,4'ünü, GSYH'nında \%11,6'sını oluşturduğu ifade edilmektedir. Bu rakamlar turizm sektörünün Türkiye açısından ne kadar önemli olduğunu ifade etmek adına faydalı göstergelerdir.

Turizm sektörünün sahip olduğu emek yoğun ve eş zamanlı tüketim gibi özellikler başarıya ulaşma konusunda insan faktörünün önemini arttırmakta (Kozak ve Kızılırmak, 2001:9) ve işgörenlerin kalifiye nitelik taşımalarını gerekli kılmaktadır (Pelit ve Güçer, 2006:140). Turizm sektöründe başarının ön şartı olarak görülen kalifiye işgücünün ise ancak etkin ve kaliteli bir turizm eğitimi (Tuna vd., 2018:44) ve bu eğitimi alanların sektörde istihdamı ile sağlanabileceği belirtilmektedir (Kuşluvan ve Kuşluvan, 2000:252). Turizmde özellikle 1980'li yıllardan başlayarak devlet desteği ve teşviklerle hızlı bir ivme yakalayan Türkiye (Türker vd., 2016:312) aynı dönemlerde sektörün hala önemli bir sorunu olarak gösterilen (Pelit ve Güçer, 2006:140) nitelikli iş gücü ihtiyacını gidermek için turizm eğitimine dönük adımlarda atmıştır (Emir vd., 2010:142). Türkiye'de yükseköğrenim düzeyinde turizm eğitimi çalışmaları 1970'li yılların ortalarında başlamıştır (Boylu, 2004:136). 1980'lerin başlarında 4 yıllık programlar açılmış ve 1990'lara kadar sınırlı gelişmeler yaşanmıştır. 1992'den sonra Türkiye'nin turizme verdiği önemin artması ve yeni açılan üniversitelerle birlikte turizm bölümlerinde artışlar yaşanmıştır (Tuna vd., 2017:43). 2009 yilına kadar yüksekokul şeklinde örgütlenen turizm lisans programlarında fakülteleşme süreci Gazi Üniversitesi, Kırklareli Üniversitesi ve Nevşehir Üniversitesi ile başlamıştır. (Bayraktaroğlu, 2013:18). Son dönemlerde turizm bölümlerine artan ilgi neticesinde devlet ve vakıf üniversitesi olmak üzere toplam 82 üniversitede lisans düzeyinde turizm eğitimi verildiği bilinmektedir (Tuna vd., 2017:46). Turizm bölümlerinde ortaya çlkan bu büyümenin sektördeki kalifiye işgücü açığının önemli bir bölümünü kapatmasına karşın sorunun hala devam ettiği görülmektedir (Pelit ve Güçer, 2006:142; Emir vd., 2010:142; Aymankuy ve Aymankuy, 2013:2; Türker vd., 2016:312). Bu sorunun nedeni önceleri eğitim kurumlarının eksikliğine bağlanırken günümüzde verilen eğitimin kalitesi ve eğitim alanların sektör algılarıyla ilişkilendirilmektedir. Kozak ve Kızılırmak (2001:9) 1980'li yıllardan sonra turizm eğitiminin esasları, amaçları, niteliği, müfredat programları ve sektöre uyumu gibi konulara yönelen çalışmaların günümüzde artık kalite, etkinlik, iş etiği, staj ve sektöre yönelik öğrenci algıları gibi daha spesifik konulara yoğunlaşttğını belirtmektedir. Bu yönelim ilgili dönemlerin kendine özgü sorunlarının çözümüne duyulan ihtiyaç ile açıklanabilir. 2000'li yıllardan sonra hızla yaygınlaşan turizm okulları ile kalifiye işgücünün eğitilmesi sağlanırken, eğitilen öğrencilerin sektörde çalışmamaları bir başka sorunu da beraberinde getirmiştir. Esasen turizm eğitimi alan öğrencilerin turizm sektörüne karşı olumsuz algıları (Aksu ve Köksal, 2005; Aymankuy ve Aymankuy, 2013) ve sektörde çalışmak istememeleri (Kuşluvan ve Kuşluvan, 2000; Işık vd., 2018) sadece Türkiye'nin karşı karşıya olduğu bir sorun değildir (Duman vd., 
2006:52; Stone vd., 2017). Richardson (2008:24) turizm sektörünün dünya genelinde nitelikli işgücü sorunuyla karşı karşıya olduğunu ifade etmektedir. Fakat günümüzde bu sorunun nedeni iş gücünün eğitilmemesinden ziyade eğitilen iş gücünün sektöre yönelmemesiyle ilgilidir. Turizm eğitimi alan öğrencilerin sektörde çalışmak istememeleri; sektörün yapısı (Pelit ve Güçer, 2006; Tuna vd., 2018), verilen eğitimin kalitesi (Tuna vd., 2018:42), öğrenci beklentileri (Stone vd., 2017:46; Richardson ve Thomas, 2012) ve sektördeki yöneticilerin tutumları (Türker vd., 2016) olmak üzere dört başlıkta ele alınabilir. Özetle turizm sektöründe işlerin mevsimlik olması, yetersiz sosyal güvence, ücretlerin düşüklüğü (Aymankuy ve Aymankuy, 2013:4), çalışma sürelerinin düzensizliği, yetersiz terfi imkanları, mesleğin statüsü (Tuna vd., 2017:44), öğrencilerin staj sürecinde yaşadığı olumsuz deneyimler (Emir vd., 2010; Erdem vd., 2018), verilen eğitimin kalitesi, eğitim kurumlarında uygulama olanaklarının yetersizliği (Soybalı ve Bayraktaroğlu, 2013), eğitim kurumları ile sektör arasında güçlü bağların kurulamaması (Aymankuy ve Aymankuy, 2013), öğrencilerin turizm alanını isteyerek tercih etmemesi (Işık vd., 2018), sektör hakkında yetersiz bilgi ile turizm eğitiminin tercih edilmesi (Kuşluvan ve Kuşluvan, 2000:261), öğrencilerin algıları ile beklentilerinin örtüşmemesi (Stone vd., 2017:46; Richardson ve Thomas, 2012; Lu ve Adler, 2009), sektördeki yöneticilerin istihdamda turizm eğitimine dikkat etmemesi (Tuna vd., 2018:44), turizm eğitimi almış olanların ücretlerinde bir farklılık gözetilmemesi (Türker vd., 2016:315) gibi faktörler turizm eğitimi alanların sektöre karşı olumsuz tutum sergilemelerine neden olmaktadır.

\section{İlgili Çalışmalar}

Literatürde az sayıda aksi sonuçlar olmasına karşın baskın görüş turizm eğitimi alan öğrencilerin sektöre karşı olumsuz tutum içerisinde olduğu yönündedir (Kuşluvan ve Kuşluvan, 2000; Aksu ve Köksal, 2005; Duman vd., 2006; Öztürk ve Pelit, 2008; Richardson, 2008; Lu ve Adler, 2009; Aymankuy ve Aymankuy, 2013). Bunun dişında yapılan çalışmalar sektörde çalışanların çok azının turizm ile ilgili bir eğitim aldığını ortaya koymaktadır. Ağaoğlu (1991) turizm sektöründe istihdam edilen iş gücünün yalnızca \%22,3'ünün turizm eğitimi aldığını ifade etmiştir. Mısırlı 2002 yılında 105 konaklama işletmesi ile gerçekleştirdiği çalışmada 412 orta kademe yöneticinin yarıdan fazlasının turizm eğitimi almadığını tespit etmiştir. Aymankuy ve Aymankuy'un (2013) aktardığı bir çalışmanın verilerine göre ise turizm sektöründe çalışanların $\% 74,8^{\prime} i$ herhangi bir düzeyde örgün turizm eğitimi almamışlardır. Aynı çalışmada turizm eğitimi almayan çalışanların oranı yiyecek içecek işletmelerinde $\% 95$, konaklama işletmelerinde $\% 89$, seyahat acentelerinde ise \%75 olarak ifade edilmiştir. Tuna ve diğerleri (2017:45) eğitim uyuşmazlığ kavramına değinerek aktardıkları bir çalışmada turizm sektöründe çalışanların neredeyse yarısının aldığı eğitim ile mevcut işi arasında bir uyumsuzluk olduğundan bahsetmektedir. Yukarıda aktarılan çalışmalar ışığında turizm sektöründeki mevcut istihdamda turizm eğitimi almış işgücünün düşük bir oranda kaldığı söylenebilir.

Hacıŏlu (1985) üniversite düzeyinde turizm eğitimi alanların sadece \%6'sının turizm sektöründe çalıştığını belirtmiştir. Türkiye ve dünyanın çeşitli ülkelerinde gerçekleştirilen pek çok çalışma turizm eğitimi alanların sektörde çalışma niyeti taşımadığını veya kısa süre içerisinde sektörü terk ettiğini göstermektedir (Tuna vd., 2017:44). Duman ve diğerlerinin (2006:52) aktardığı bir çalışmada turizm eğitimi alan öğrencilerin \%20'sinin mezuniyetten sonraki ilk yılda \%33'ünün ise 5. yılda sektörden ayrıldıkları ifade edilmiştir. Richardson (2008) turizm eğitimi 
alanların yarıdan fazlasının sektörde çalışmayı düşünmediklerini ve neredeyse tamamının aldığ bu kararda sahip oldukları sektör deneyiminin etkili olduğunu belirtmektedir. Çeşitli çalışmalarda sektör deneyimi, staj ve üst sınıflarda bulunma gibi faktörlerin öğrencilere sektör hakkında bilgi edinme şansı tanıdığından dolayı sektöre karşı algılarının olumsuz yönde etkilenmesine neden olduğu belirtilmektedir (Kozak ve Kızılırmak, 2001; Pelit ve Güçer, 2006; Duman vd., 2006; Emir vd., 2010; Türker vd., 2016).

Benzer çalışmalarda kadın öğrencilerin eğitim sürecinde daha başarılı olduğu belirtilirken erkeklerin ise sektörde daha başarılı olduğu görülmektedir (Şahin ve Arman, 2014). Öğrencilerin cinsiyetlerine göre sektöre karşı geliştirdikleri algılarında ise anlamlı fark bulunmadığı çeşitli çalışmalarda belirtilmektedir (Kozak ve Kızılırmak, 2001:12; Türker vd., 2016:325). Bunun dışında kişilik özelliklerinden dişa dönüklük öğrencilerin sektörde kariyer yapma isteğine olumlu etki etmektedir (Tuna vd., 2017:45). Öğrencilerin lisans veya ön lisans düzeyinde turizm eğitimi almasının da sektör algılarında farklılaşmaya neden olduğu ve ön lisans düzeyinde eğitim alanların daha olumlu bir yaklaşım içerisinde olduğu bilinmektedir (Türker vd., 2016:326).

Pelit ve Güçer (2006:40) öğrencilerin ve turizm işletmelerinin staj sürecinden beklentilerinin farklı olduğunu belirtmektedirler. Erdem ve diğerleri (2018:77) ise bu beklentilerin çoğu zaman çeliştiğini ifade etmektedir. Emir ve diğerleri (2010) tarafından eşleştirilmiş örneklerde $t$ testi yöntemi kullanılarak 2009 yılı Mayıs ayında staj başvurusu yapan 176 öğrenci üzerinde yapılan çalışmada öğrencilerin staj öncesi ve staj sonrası düşünceleri karşılaştırılmıştır. Çalışma sonuçlarına göre öğrencilerin staj sonrası görüşleri tecrübe ve farklı kültürleri tanıma dışında bütün alanlarda daha olumsuzdur. Bu bulguların tersine Erdem ve diğerleri (2018) Kırgız öğrencilerin Türkiye'de yapmış oldukları staj deneyimlerinin değerlendirilmesine ilişkin gerçekleştirdikleri çalışmada öğrencilerin genel olarak memnun kaldıklarını ifade etmiştir. Richardson (2010) ise Avusturalya'da yerel ve yabancı öğrencilerin turizm sektör algılarını karşılaştırmış ve yabancı uyrukluların daha olumlu bir bakış açısına sahip olduğunu bulmuştur.

Özetle, ilgili çalışmalar sektörde eğitimli iş gücü istihdamının düşük olduğunu, öğrencilerin deneyim ve staj gibi sektör hakkında bilgi edinmelerini sağlayan uygulamalardan sonra sektöre ilişkin daha olumsuz düşüncelere sahip olduğunu, ön lisans öğrencilerinin lisans öğrencilerine göre sektöre daha olumlu baktıklarını, ülkeleri dışında staj yapan veya öğrenim gören yabancı uyruklu öğrencilerin sektör algılarının daha olumlu olduğunu göstermektedir.

\section{YÖNTEM}

Belirli bir sektörün imajı, gelecekte o sektörde istihdam edilecek personelin sayı ve kalitesini belirleyecek olan potansiyel iş gücünün sektöre karşı alg1 ve tutumu üzerinde büyük bir etkiye sahiptir (Stone vd., 2017:46). İşgörenlerin bir sektöre bağlılığı ise sektörün sunduğu iş imkanlarının yanı sıra işgörenlerin algı ve tutumları tarafından belirlenmektedir (Richardosn, 2009). Günümüzde turizm eğitimi alan öğrencilerin sektöre karşı alg1 ve tutumlarının olumsuz yönde geliştiğini gösteren birçok çalışma yürütülmektedir. Bu çalışmalarda öğrencilerin sektör algıları demografik özelliklerine göre, sektör deneyimlerine göre, staj yapma ve yapmama durumlarına göre geniş bir biçimde ele alınmıştır. Bu çalışma ise öğrencilerin lisans düzeyinde turizm eğitimine başlamadan önceki algıları ile başladıktan 2 yıl sonra oluşan algılarının karşılaştırılmasını amaçlamaktadır. Literatürde üst sınıfta bulunan (Tuna vd., 2017) ve sektör 
tecrübesi olan öğrencilerin (Kozak ve Kızılırmak, 2001) sektöre karşı daha olumsuz algı ve tutum geliştirdiği ifade edilmektedir. Öğrencilerin, eğitim sürecinde ve sektör tecrübesi ile sektör hakkında daha gerçekçi bilgiler edinmesinin, olumsuz algılarının gelişmesinde etkili olduğu belirtilmektedir (Işık vd., 2018). İlgili çalışmalardan farklı olarak bu çalışmada eşleştirilmiş örneklerde t-testi yöntemi kullanılarak iki yıllık bir süreç içerisinde sektör algılarının aynı öğrenci grubu üzerinde ölçülmesi sağlanmıştır. Bu yöntemle aynı öğrencilere ait sektör algılarının eğitime başlamadan önce ve eğitim sürecinde nasıl bir değişim geçirdiği izlenebilmektedir. Bu durum ise üst sınıflarda bulunan öğrencilerin algılarında ortaya çıkan olumsuz düşüncelerin onların kendine özgü birtakım nedenlerden dolayı ortaya çıkma ihtimalini ortadan kaldırarak eğitim öncesinde ve eğitim sürecinde aynı öğrencilere ilişkin algıların ölçülmesine imkan sağlamaktadır.

Çalışma Selçuk Üniversitesi, Beyşehir Ali Akkanat Turizm Fakültesi, 2016-2017 yılında Turizm İşletmeciliği bölümüne kayıt yaptıran 73 öğrenci üzerinde gerçekleştirilmiştir. Çalışmada sektör algılarının ölçülmesine ilişkin literatür taraması ile oluşturulan, faktör analizi ile geçerliliği sağlanan ve Cronbach Alpha değeri $(0,720)$ ölçülerek güvenilirliği test edilen anket formu kullanılmıştır. Anketler aynı öğrencilere Eylül 2016 ve Haziran 2018 tarihlerinde, numaralandırılarak uygulanmıştır. 2016 yılında kayıt yaptıran 73 öğrenciden 30'u çeşitli nedenlerden dolayı okula devam etmediği için 2018 yılında uygulanan anket sayısı 43'e düşmüştür.

\section{BULGULAR}

Tablo 1 araştırmaya katılan öğrencilere ilişkin veriler 2016 (öncesi) ve 2018 (sonrası) olmak üzere iki ayrı sütunda verilmiştir.

2016 yılında fakültemizin Turizm İşletmeciliği bölümüne kayıt yaptıran 73 öğrenci bulunmaktadır. Bu öğrencilerden bir kısmı kayıttan sonra fakülteye hiç gelmezken, bir kısmı geçiş yapmış ve bir kısmı da kayıt sildirmiştir. Sonuç olarak 2018 yılına gelindiğinde 2016 yılında kayıt yaptıran sadece 43 öğrencinin eğitimlerine devam ettiği anlaşılmıştır. Öğrencilerin çoğunluğu erkeklerden oluşmaktadır. Sektörde çalışma niyetleri incelendiğinde \%84 ile büyük bir bölümünün çalışma niyeti taşıdığı görülmesine karşın 2018 yılında bu oranın \%54'e düştüğü görülmektedir. Öğrencilerin çoğu 2016 ve 2015 yılında liseden mezun olmuşlardır ve büyük oranda genel lise mezunudurlar.

Kuşluvan ve Kuşluvan (2000), Kızılırmak ve Kozak (2001), Duman ve diğerleri (2006), Emir (2013), Türker ve diğerlerinin (2016) çalışmalarından yararlanılarak hazırlanan anket formunda "Sektöre Bağlılık, Gelir ve Kazançlar, Sosyal Statü, Çalışma Koşulları, İşin Doğası" olmak üzere 5 farklı boyutta 24 önerme hazırlanmıştır. Daha sonra anket ilk uygulanan 73 kişilik grup verilerine göre Faktör Analizine tabi tutulmuştur. Verilerin faktör analizine uygunluğu için KMO ve Barlett Örneklem Yeterlilik Testi uygulanmıştır. KMO sonuçları 0,635 ve Bartlett's testi olasılık değeri de 0,000 olarak hesaplanmıştır. Bu sonuçlar verilerin faktör analizine uygun olduğunu göstermektedir. 
Tablo 1 Katılımcıların Demografik Verileri

\begin{tabular}{|c|c|c|c|c|c|}
\hline \multirow[t]{2}{*}{ Sorular } & \multirow[t]{2}{*}{ Cevaplar } & \multicolumn{2}{|c|}{$\begin{array}{c}\text { Öncesi } \\
2016\end{array}$} & \multicolumn{2}{|c|}{$\begin{array}{c}\text { Sonrasi } \\
2018\end{array}$} \\
\hline & & $\mathrm{n}$ & $\%$ & $\mathrm{n}$ & $\%$ \\
\hline \multirow{2}{*}{ Cinsiyet } & Kadın & 19 & 26 & 12 & 28 \\
\hline & Erkek & 54 & 74 & 31 & 72 \\
\hline \multirow{3}{*}{$\begin{array}{l}\text { Sektörde Çalışma } \\
\text { Niyeti }\end{array}$} & Evet & 61 & 84 & 23 & 54 \\
\hline & Hayır & 4 & 6 & 18 & 42 \\
\hline & Kararsiz & 8 & 10 & 2 & 4 \\
\hline \multirow{4}{*}{ Lise Mezuniyet Tarihi } & 2016 & 33 & 46 & 21 & 49 \\
\hline & 2015 & 26 & 36 & 14 & 33 \\
\hline & 2014 & 7 & 9 & 4 & 9 \\
\hline & 2013 ve Öncesi & 7 & 9 & 4 & 9 \\
\hline \multirow{5}{*}{ Lise Türü } & Genel Lise & 26 & 36 & 15 & 35 \\
\hline & Meslek Lisesi & 21 & 30 & 12 & 28 \\
\hline & Anadolu Lisesi & 14 & 20 & 9 & 21 \\
\hline & Turizm Lisesi & 1 & 2 & 1 & 3 \\
\hline & Diğer Liseler & 9 & 12 & 6 & 13 \\
\hline Toplam & Kişi Sayısı & \multicolumn{2}{|c|}{73} & \multicolumn{2}{|c|}{43} \\
\hline
\end{tabular}

Tablo 2'de faktör analizi sonucunda oluşan boyutların açıkladığı varyans oranları, boyutlara ilişkin öz değerler, önermelerin faktör yükleri ve ortalamaları verilmiştir.

Anket formu için hazırlanan 24 önermeden 6 tanesi faktör yükünün düşük hesaplanması veya birden fazla faktöre yakın değerlerle yüklenmesinden dolayı çıkarılarak faktör analizi toplamda $7 \mathrm{kez}$ tekrarlanmış ve alt boyut sınırlaması yapılmaksızın önermelerin 5 farklı boyutta toplandığ 1 görülmüştür. Toplam açıklanan varyans yaklaşık \%71 olarak hesaplanmıştır.

Aşağıdaki tabloda araştırmada kullanılan boyut ortalamalarının normal dağılımlarını gösteren Shapiro-Wilk test istatistikleri yer almaktadır. Gözlem sayısının 50'den az olduğu durumlarda Shapiro-Wilk, fazla olduğu durumlarda ise Kolmogrov-Smirnov testi önerilmektedir (Çinko ve diğerleri, 2013:66). Çalışmada, yapılan ilk ankette 74 kişiye, son ankette ise 74 kişiden sadece 43 'üne ulaşılabilmiştir. Dolayısıyla yapılan analizlerde gözlem sayısı 43 olarak ele alınmıştır. Bu bağlamda Shapiro-Wilk testi sonuçlarına göre normal dağılıma karar verilmiştir.

Verilerin normal dağıldığını söyleyebilmek için hesaplanan olasılık değerlerinin 0,05'ten büyük olması gerekmektedir. Tabloda öncesi ve sonrası toplam 10 boyuttan bu şartı sağlayan 6 boyut bulunmaktadır. Bu şartı sağlamayan boyutlar için çarpıklık ve basıklık değerleri incelenebilir. Genel kanıya göre çarpıklık ve basıklık değerlerinin $+1,5$ ile $-1,5$ arasında olması verilerin normal dağılım varsayımı için yeterlidir (Tabachnick ve Fidell, 2013). Yukarıda verilen boyutlardan Shapiro-Wilk testine göre $0,05^{\prime}$ ten küçük olasılık değerine sahip olanların normal dağılmadığı söylenebilir fakat bu boyutların çarpıklık ve basıklık değerleri incelendiğinde ise kabul gören 1,5 ile $+1,5$ aralığında olduğu görülmektedir. Bu durum verilerin normal dağılım varsayımını karşılamaktadır 
Tablo 2 Faktör Analizi Sonuçları ve Değişkenlerin Ortalamaları

\begin{tabular}{|c|c|c|c|c|c|}
\hline Önermeler \Faktörler & $\begin{array}{l}\text { Fakt. } \\
\text { Yük. }\end{array}$ & $\begin{array}{l}\text { Öz } \\
\text { Değ. }\end{array}$ & $\begin{array}{l}\text { Açık. } \\
\text { Var. }\end{array}$ & $\begin{array}{c}\text { Ort. } \\
(2016)\end{array}$ & $\begin{array}{c}\text { Ort. } \\
(2018)\end{array}$ \\
\hline \multicolumn{6}{|c|}{ Faktör 1; Sektöre Bağlılık } \\
\hline Bir meslek olarak turizmi seçtiğim için mutluyum. &, 800 & \multirow{5}{*}{4,32} & \multirow{5}{*}{24,04} & 4,17 & 3,05 \\
\hline $\begin{array}{l}\text { Mezun olduktan sonra turizm sektöründe } \\
\text { çalışmak isterim. }\end{array}$ & 784 & & & 4,24 & 3,07 \\
\hline $\begin{array}{l}\text { Çevremdekilere turizm sektöründe çalışmalarını } \\
\text { öneririm. }\end{array}$ & ,762 & & & 3,80 & 2,95 \\
\hline $\begin{array}{l}\text { Turizm sektöründe iş sahibi olmak için büyük bir } \\
\text { çaba sarf edeceğim. }\end{array}$ & ,614 & & & 4,12 & 3,26 \\
\hline $\begin{array}{l}\text { Mezun olduktan sonra turizmle ilgili bir iş } \\
\text { yapacağım }\end{array}$ &,- 592 & & & 4,08 & 3,50 \\
\hline \multicolumn{6}{|c|}{ Faktör 2; Gelir ve Kazançlar } \\
\hline $\begin{array}{l}\text { Turizmde birçok iş için ödenen ücretler çok } \\
\text { düşüktür. }\end{array}$ &, 847 & \multirow{4}{*}{3,22} & \multirow{4}{*}{17,92} & 2,67 & 3,81 \\
\hline $\begin{array}{l}\text { Turizm sektöründe verilen maaşlar rahat bir } \\
\text { hayat sürdürebilmek için yeterli değildir. }\end{array}$ & ,747 & & & 2,69 & 3,43 \\
\hline $\begin{array}{l}\text { Uzun çalışma süresi ve iş yükü göz önüne } \\
\text { alındığında verilen ücretler çok düşüktür. }\end{array}$ & 735 & & & 2,88 & 3,74 \\
\hline $\begin{array}{l}\text { Turizm sektöründe çalışanlara sağlanan ekstra } \\
\text { imkanlar yetersizdir (tatil, eğlence, ikramiye vb.). }\end{array}$ & ,634 & & & 2,92 & 3,90 \\
\hline \multicolumn{6}{|c|}{ Faktör 3; Sosyal Statü } \\
\hline $\begin{array}{l}\text { Turizm sektöründe olmak toplumda saygın bir } \\
\text { yere sahip olmamızı sağlar. }\end{array}$ &, 800 & \multirow{3}{*}{2,25} & \multirow{3}{*}{12,53} & 3,59 & 2,86 \\
\hline $\begin{array}{l}\text { Turizmde çalışmak toplum için önemli ve yararlı } \\
\text { bir hizmet olarak kabul edilir. }\end{array}$ & ,760 & & & 3,98 & 3,17 \\
\hline $\begin{array}{l}\text { Turizm sektöründe çalışanların toplumda değerli } \\
\text { olduğunu düşünüyorum. }\end{array}$ &, 579 & & & 3,97 & 2,57 \\
\hline \multicolumn{6}{|c|}{ Faktör 4; Fiziki Çalışma Koşulları } \\
\hline $\begin{array}{l}\text { Turizm sektöründe yüksek iş kazası riski } \\
\text { bulunmaktadır. }\end{array}$ &, 722 & \multirow{3}{*}{1,53} & \multirow{3}{*}{8,501} & 1,89 & 2,48 \\
\hline $\begin{array}{l}\text { Turizm sektöründe çalışma alanları çok } \\
\text { gürültülüdür. }\end{array}$ & 643 & & & 1,98 & 2,90 \\
\hline Turizmde çalışma ortamı temiz değildir. & 623 & & & 1,48 & 2,24 \\
\hline \multicolumn{6}{|c|}{ Faktör 5; İşin Doğası } \\
\hline Turizm sektöründeki birçok iş düşük niteliktedir. & ,719 & \multirow{3}{*}{1,44} & \multirow{3}{*}{8,000} & 2,11 & 3,02 \\
\hline Turizmde yapılan işler genellikle sıkıcıdır. & 638 & & & 1,53 & 2,29 \\
\hline Turizm sektöründe yapılan işler çok streslidir. &, 470 & & & 1,98 & 3,24 \\
\hline
\end{tabular}


Tablo 3 Shapiro-Wilk Testi, Çarpıklık ve Basıklık Değerleri

\begin{tabular}{|c|c|c|c|c|c|}
\hline \multirow{2}{*}{ Boyutlar } & \multicolumn{3}{|c|}{ Shapiro-Wilk } & \multirow{2}{*}{ Çarpıklık } & \multirow{2}{*}{ Basıklık } \\
\hline & Statistic & $\mathrm{df}$ & Sig. & & \\
\hline \multicolumn{6}{|c|}{ Öncesi (2016) } \\
\hline İşin Doğası & ,940 & 43 & ,025 & 0,039 & $-0,866$ \\
\hline Sosyal Statü & ,974 & 43 & ,446 & $-0,048$ & 0,259 \\
\hline Fiziki Çalışma Koşulları & ,848 & 43 & ,020 & $-0,443$ & 1,204 \\
\hline Gelir ve Kazançlar & ,940 & 43 & ,025 & 0,039 & $-0,866$ \\
\hline Sektöre Bağlılık &, 874 & 43 &, 000 & $-0,870$ & $-0,134$ \\
\hline \multicolumn{6}{|c|}{ Sonrasi (2018) } \\
\hline İşin Doğası & ,956 & 43 & ,097 & 0,483 & $-0,072$ \\
\hline Sosyal Statü & ,980 & 43 & ,651 & 0,204 & $-0,474$ \\
\hline Fiziki Çalışma Koşulları & ,952 & 43 &, 069 & 0,620 & 0,700 \\
\hline Gelir ve Kazançlar & ,981 & 43 & 696 & $-0,045$ & $-0,224$ \\
\hline Sektöre Bağlılık & ,966 & 43 & ,224 & 0,412 & 0,802 \\
\hline
\end{tabular}

Normal dağılım varsayımı desteklendikten sonra öğrencilerin eğitim öncesi (2016) ve eğitim süreci (2018) içerisinde gelişen turizm sektörüne ilişkin algılarının karşılaştırılması için eşleştirilmiş örneklerde t-testi uygulanmıştır. Kullanılan ankette "İşin Doğası, Fiziki Çalışma Koşulları, Gelir ve Kazançlar" boyutlarına ilişkin önermeler olumsuz ifadelerden oluşmakta iken "Sosyal Statü ve Sektöre Bağlllık" boyutlarına ilişkin önermeler olumlu ifadelerden oluşmaktadır.

Tablo 4 Eşleştirilmiş Örneklerde t-testi Ortalama Tablosu

\begin{tabular}{llcccc}
\hline & $\begin{array}{l}\text { Boyut Eşleştirmeleri } \\
\text { (Öncesi ve Sonrası) }\end{array}$ & Ortalama & N & $\begin{array}{c}\text { Std. } \\
\text { Sapma }\end{array}$ & $\begin{array}{c}\text { Standart } \\
\text { Hata Ort. }\end{array}$ \\
\hline \multirow{2}{*}{ Eşleştirme 1 } & İşin Doğası (2016) & 1,9710 & 43 &, 91503 &, 13954 \\
& İşin doğası (2018) & 2,8217 & 43 & 1,06246 &, 16202 \\
\hline \multirow{2}{*}{ Eşleştirme 2 } & Sosyal Statü (2016) & 3,2225 & 43 &, 70323 &, 10724 \\
& Sosyal Statü (2018) & 2,8372 & 43 &, 92688 &, 14135 \\
\hline \multirow{2}{*}{ Eşleştirme 3 } & Fiziki Çalışma Koşulları (2016) & 1,7176 & 43 &, 82842 &, 12633 \\
& Fiziki Çalışma Koşulları (2018) & 2,5426 & 43 & 1,11750 &, 17042 \\
\hline \multirow{2}{*}{ Eşleştirme 4 } & Gelir ve Kazançlar (2016) & 2,8371 & 43 & 1,25186 &, 19091 \\
& Gelir ve Kazançlar (2018) & 3,6686 & 43 & 1,17479 &, 17915 \\
\hline \multirow{2}{*}{ Eşleştirme 5 } & Sektöre Bağlılık (2016) & 3,5962 & 43 &, 77777 &, 11861 \\
& Sektöre Bağlılık (2018) & 3,0144 & 43 &, 86060 &, 13124 \\
\hline
\end{tabular}


Yukarıdaki tablo 2016 (öncesi) ve 2018 (sonrası) yıllarında ölçülmüş olan öğrenci algılarının boyutlara ilişkin ortalamalarını vermektedir. Boyutlara ilişkin ortalamalarda düşük düzeylerde de olsa farkların ortaya çıktı̆̆ görülmektedir. İşin Doğası, Fiziki Çalışma Koşulları, Gelir ve Kazançlar boyutlarında ortalamanın yükseldiği diğer boyutlarda ise düştüğü anlaşılmaktadır. Ortalamalarında artış yaşanan boyutların olumsuz ifadelerden oluşan boyutlar olduğu görülmektedir. Dolayısıyla bütün boyutlara ilişkin sonraki ölçümlerde öğrencilerin algılarının olumsuz yönde değiştiği söylenebilir. Bu sonuç çeşitli çalışmalar tarafından desteklenmektedir (Kuşluvan ve Kuşluvan, 2000; Türker vd., 2016; Işık vd., 2018).

Boyutlara ilişkin öncesi ve sonrası ölçümlerde ortaya çıkan değişimin istatistiki olarak anlamlılığına karar vermek için aşağıdaki eşleştirilmiş örneklerde t-testi tablosu kullanılabilir.

Tablo 5 Eşleştirilmiş Örneklerde t-testi Tablosu

\begin{tabular}{|c|c|c|c|c|c|c|c|}
\hline & \multirow[b]{2}{*}{$\begin{array}{c}\text { Eşleştirmeler } \\
\text { Öncesi - Sonrası }\end{array}$} & \multicolumn{3}{|c|}{ Eşleştirme Farkları } & \multirow[b]{2}{*}{$\mathbf{t}$} & \multirow[b]{2}{*}{ df } & \multirow[b]{2}{*}{ Sig. } \\
\hline & & Ort. Fark1 & $\begin{array}{c}\text { Std. } \\
\text { Sapma }\end{array}$ & $\begin{array}{l}\text { Std. Hata } \\
\text { Ort. }\end{array}$ & & & \\
\hline Eş. 1 & İ. D. 1 - İ. D. 2 &,- 85072 & 1,32348 & 20183 & $-4,215$ & 42 & ,000 \\
\hline Eş. 2 & S.S. $1-$ S. S. 2 & ,38534 & 1,20230 & 18335 & 2,102 & 42 & 042 \\
\hline Eş. 3 & F. Ç. K. 1 - F. Ç. K. 2 &,- 82503 & 1,19354 & 18201 & $-4,533$ & 42 & ,000 \\
\hline Eş. 4 & G. K. 1 - G. K. 2 &,- 83149 & 1,35277 & ,20630 & $-4,031$ & 42 & ,000 \\
\hline Eş. 5 & S. B. 1 -S. B. 2 & 58179 & 1,04802 & 15982 & 3,640 & 42 & ,001 \\
\hline
\end{tabular}

Tabloda yer alan 5 eşleştirme için hesaplanan olasılık değerleri incelendiğinde öncesi ve sonrası ölçümlerde ortaya çıkan farkların anlamlı olduğu görülmektedir $(\mathrm{p}<0,05)$. İşin doğası (Eş. 1), Fiziki çalışma koşulları (Eş. 3), Gelir ve kazançlar (Eş. 4) olmak üzere üç boyutta öncesi (2016) ölçümlerin sonrası (2018) ölçümlerden daha yüksek ortalamaya sahip olduğu görülmektedir. Yukarıda da belirtildiği üzere bu durum ilgili boyutlara ait önermelerin olumsuz nitelik taşımasından kaynaklanmaktadır. Dolayısıyla bütün boyutlar için sonrası (2018) ölçümlerin öncesi (2016) ölçümlerden daha olumsuz sonuçlandığı söylenebilir. Öğrenciler fakülteye kayıt olmadan önce turizm sektörüne ilişkin bu beş boyutta daha olumlu düşüncelere sahipken 2 . Sınıfın sonuna geldiklerinde daha olumsuz düşünmeye başlamışlardır. Ortalama farkları incelendiğinde değişim düzeyinin en yüksek İşin Doğası $(0,85072)$, Gelir ve Kazançlar $(0,83149)$ ve Fiziki Çalışma Koşulları $(0,82503)$ boyutlarında ortaya çıtığı görülmektedir. En düşük düzeyde değişim ise Sosyal Statü $(0,38534)$ ve Sektöre Bağlllık $(0,58179)$ boyutlarında gözlemlenmiştir.

Öğrencilerin turizm sektörünün cazibesinden etkilenerek (Iş̧1k ve diğerler, 2018) ve sektör hakkında doğru bilgilerden yoksun bir şekilde tercihte bulunması (Stone ve diğerleri, 2017) eğitim sürecinde sahip oldukları bilgi düzeyinin artmasıyla algılarının olumsuz yönde değişmesine neden olabilir. Dolayısıyla düşük düzeyde değişim gösteren Sosyal Statü ve Sektöre Bağllıık konularında öğrencilerin eğitim öncesinde sahip oldukları algının eğitim sürecinde edindikleri bilgi ile göreceli olarak daha uyumlu olduğu ve bundan dolayı algılarında yüksek 
düzeyde fark oluşmadığı fakat İşin Doğası, Gelir ve Kazançlar, Fiziki Çalışma Koşulları boyutlarına ilişkin eğitim öncesi sahip oldukları bilgileri ile eğitim sürecinde edindikleri yeni bilgilerin uyuşmadığı ve yeni edinilen bilgiler neticesinde algılarında olumsuz yönde değişimlerin yaşandığı söylenebilir.

Öğrencilerin öncesi ve sonrası ölçümlerde turizm sektörü algılarına ilişkin ortaya çıkan farkların neden kaynaklandığını anlamak adına öğrencilerin geçirmiş olduğu bu iki yıllık süreçte nelerin değiştiğini ifade etmek önemlidir. Bu süreçte değişim gösteren unsurları demografik özellikler, teorik bilgi düzeyi ve deneyim olmak üzere üç başlıkta ele almak mümkündür. Demografik olarak öğrencilerin bu süreçte 2 yaş büyüdüğü söylenebilir. Teorik bilgi düzeyleri ise verilen derslerle bu iki yıl içerisinde önemli ölçüde artmıştır. Deneyim yönünden ise öğrenciler bu iki yıl içerisinde müfredatlarında bulunan iki farklı uygulama dersi kapsamında toplam bir ay otel işletmelerinde tecrübe kazanmışlardır. Bunun dışında gönüllü öğrencilere fakültenin bağlantılı olduğu otellerde yazın çalışma imkanı sunularak deneyim kazanmaları sağlanmıştır. Kuşluvan ve Kuşluvan'ın (2000:255) belirttiği gibi öğrenciler 3. ve 4. Sınıfa geldiklerinde en az 3 ay sektör deneyimine sahip olmaktadırlar. Deneyim konusunda öncesi ve sonrası ölçümlerde ortaya çıkan fark aşağıdaki tabloda verilmiştir.

Tablo 6 Deneyime İlişkin Öncesi ve Sonrası Ortalamaları

\begin{tabular}{lcccc}
\hline $\begin{array}{c}\text { Deneyim Eşleştirmeleri } \\
\text { (Öncesi ve Sonrası) }\end{array}$ & Ortalama & N & $\begin{array}{c}\text { Std. } \\
\text { Sapma }\end{array}$ & $\begin{array}{c}\text { Standart } \\
\text { Hata Ort. }\end{array}$ \\
\hline Sektör Deneyimi (2016) & 1,4651 & 43 & 3,09646 &, 47221 \\
Sektör Deneyimi (2018) & 3,3023 & 43 & 3,97333 &, 60593 \\
\hline
\end{tabular}

Tablo 6 sektör deneyimine ilişkin öncesi ve sonrası ölçümleri göstermektedir. Bu bağlamda öğrencilerin kayıt esnasında ortalama deneyimleri 1,4 ay iken 2018 ölçümlerinde 3,3 aya çıtığ 1 görülmektedir. Ortalama 2 aylık bir fark göze çarpmaktadır. İlk yapılan ölçümlere göre kayıt yaptıran 48 öğrencinin sektöre ilişkin hiç deneyimi yoktur, 10 öğrencinin 3 ay civarında ve geri kalan 15 öğrencinin ise 3-9 ay arası bir deneyime sahip olduğu görülmektedir. Son yapılan ölçümlerde ise her öğrencinin en az 1 ay deneyime sahip olduğu ve öğrenci başına deneyimin ortalama 2 ay artış gösterdiği görülmüştür.

Literatürde öğrencilerin turizm sektörü algılarının olumsuz yönde değişmesine neden olan en önemli etkenin deneyim olduğu belirtilmektedir (Stone vd., 2017:41). İlgili çalışmalarda stajla kazanılan deneyim üzerinde sıklıkla durulmakta ve öğrencilerin sektör algılarının olumsuz yönde değişmesine neden olduğu ifade edilmektedir (Kozak ve Kızılırmak, 2001; Tuna vd., 2017).

\section{SONUÇ ve ÖNERILER}

Öğrencilerin eğitim aldıkları sektöre karşı tutumlarının, onların eğitim sürecinde akademik başarılarına, uygulanan eğitim programının başarısına, öğrencilerin gelecekte atılacağı çalışma hayatındaki başarılarına, mesleklerini sevmelerine ve öğrencilerden alınan geri bildirimler neticesinde ders müfredatlarının oluşturulması sürecine, öğretim yöntemlerinin belirlenmesine 
önemli düzeyde etki etmektedir (Kozak ve Kızllırmak, 2001:10). Kalifiye iş gücünün sektöre yönelmesi ve sektörde tutulması bakımından da öğrencilerin sektöre karşı tutumları önemlidir (Tuna vd., 2017). Bu çalışmada lisans düzeyinde turizm eğitimi alan öğrencilerin eğitime başlamadan önceki sektör algıları ile 2. sınıfta oluşan sektör algıları eşleştirilmiş örneklerde t-testi yöntemiyle karşılaştırılmıştır. Sonuç olarak öğrencilerin sektör algılarının bütün boyutlarda olumsuz yönde değiştiği tespit edilmiştir. Bunun nedeni öğrencilerin eksik bilgi ile (Stone vd., 2017) turizm sektörünün cazibesine kapılarak bilinçsiz bir şekilde bu bölümü tercih etmesi (Işık vd., 2018) ve eğitim sürecinde kazandığı teorik bilgi ve deneyim sonucu sektör algılarının olumsuz yönde değişmesi olabilir. Benzer çalışmalarda üst sinıflarda bulunan ve sektör deneyimine sahip öğrencilerin daha olumsuz sektör algısına sahip olduğu ifade edilmektedir (Türker vd., 2016; Tuna vd., 2017). Bu durum öğrenci beklentilerinin sektör gerçekleri ile uyuşmamasının bir sonucudur (Richardson ve Thomas, 2012). Örneğin, öğrencilerin büyük bir bölümü mezun olduktan sonra orta kademe yöneticilik pozisyonunda bir iş ummaktadır (Stone vd., 2017:33). Fakat bu beklenti daha eğitim sürecinde öğrencinin edindiği niteliksiz işlerdeki deneyim ile yerini umutsuzluğa bırakmaktadır. Öğrencilerin çok azı mezun olduğunda orta kademe yönetici pozisyonuna ulaşabilmektedir. Bu durum ise sektörde turizm eğitimi almış olmanın gözetilmemesi (Türker vd., 2016), yetersiz terfi imkanları (Tuna vd., 2017) ve öğrencilerin gerekli donanıma ulaşamamalarından kaynaklanmaktadır.

Bir diğer önemli sonuç ise öğrencilerin sektör algılarının olumsuz yönde değişmesine karşın hala büyük bir bölümünün (\%54) sektörde çalışma niyeti taşımasıdır. Bu sonuç Duman ve diğerlerinin (2006), Tuna ve diğerlerinin (2017) çalışmaları ile örtüşmektedir. Bu durumun nedeni mevcut alternatif iş imkanları, sektör bağlılığı ve sektör kişilik uyumu ile açıklanabilir. A.S.A. (atractionselection-attrition) teorisine göre kişiler, kendi tutum ve inanışlarıyla aynı değerde veya paralel olduğuna inandıkları işlere girme fırsatlarını ararlar. Güçlü bir iş tecrübesi olmayanlar, kendilerini kısa süre sonra sektörün dışına atabilirler (Çakıcı ve Özdamar, 2018:45). Dolayısıyla öğrencilerin kişilikleri ile turizm sektörü uyumları sektörde çalışma niyeti taşımalarını sağlarken iş tecrübelerindeki eksiklik onların sektörden kolayca vazgeçmelerine neden olabilir.

Öğrencilerin eğitime başlamadan önce sektöre karşı sahip oldukları olumlu algılarının zamanla olumsuz yönde değişmesi ve bu durumun ilgili literatürde büyük oranda sektör hakkında edinilen bilgi ve kazanılan deneyime bağlanması yaşanan bu sorunun büyük ölçüde öğrenci beklentileri ve sektör gerçekleri arasındaki uyuşmazlıktan kaynaklandığını göstermektedir. Bu uyuşmazlığın nedeni ise bilinçsiz yapılan eğitim alanı tercihleridir. Dolayısıyla turizm sektörünün gerçeklerini bilerek bu sektörde çalışmaya talip olacak öğrencilerin bu alanı seçmesi sağlanmalıdır. Fakat günümüzde turizm bölümleri özellikle lisans düzeyinde eğitim verenler, öğrencilerin en düşük puanlarla giriş yapabildiği bölümlerdir. Bu durum aslında öğrencilerin başka hiçbir bölüm kazanamadığında bu bölümlere yönelmesine neden olabilir. Bunun sonucunda da sektörde çalışmayan ama sektör eğitimi almış bir insan ordusu oluşur. Her ne kadar yapılan araştırmalarda öğrencilerin yarıdan fazlasının bu bölümü isteyerek tercih ettiği (Tuna vd., 2017) ifade edilse de bu öğrencilerin birçoğunun farklı bölümleri arzuladığı, yürütülen çalışmalarda turizm öğrencilerinin turizm sektörüne ilişkin algılarının büyük oranda olumsuz sonuçlanmasından dolayı düşünülebilir.

YÖK (2017) tarafından yayınlanan LYS Yerleştirme Analizi raporunda Turizm İşletmeciliği lisans bölümünde 3.790 kontenjandan \%50 ile sadece 1.897'sinin dolduğu belirtilmektedir. Fakat ÖSYM tarafından yayınlanan 2017 ÖSYS yerleştirme istatistiklerinde Otelcilik ve Turizm Meslek Lisesi 
Mezunu 16.316 adayın sınava başvuru yaptığı ve bunlardan 1.324'ünün lisans düzeyinde, 3.949'unun ön lisans düzeyinde ve 1.004'ünün ise açık öğretimde bir programa yerleştiği ifade edilmektedir. İlgili çalışmalarda ön lisans düzeyinde eğitim alanların sektöre karşı daha olumlu tutum içerisinde olduğu (Türker vd., 2016) ve sektörde kalmaya daha eğilimli olduğu (Tuna vd., 2017) ifade edilmektedir. Bununla birlikte bu çalışmada da görüldüğü gibi lisans düzeyinde turizm eğitimi veren fakültelerde Turizm Lisesi çıkşslı öğrenci oranı çok düşük düzeyde kalmaktadır. Bu bağlamda turizm sektörüne karşı daha olumlu algıya sahip olma ihtimali yüksek olan turizm lisesi mezunlarının turizm fakültelerinde \%50 oranda boş kalan kontenjanlarla buluşturulmasını sağlayacak yeni düzenlemelerin yapılması, açık kalan kontenjanlar ve sektörde çalışacak kalifiye iş gücü sorunlarının çözülmesi açısından önemlidir. Böylece sektörde çalışmayacak insanlara sektör eğitimi verilerek boşa harcanan zamandan ve emekten tasarruf etmenin yanı sıra (Stone vd., 2017) sektörde yaşanan iş gücü devir hızının da (Tuna vd., 2017) önüne geçilebilir.

Yükseköğrenimin değişen yüzü üniversiteler üzerinde daha mesleki bir eğitimin uygulanması konusunda baskı oluşturmaktadır (Stone vd., 2017:42). Daha mesleki bir eğitim ise ilgili sektörler ile eğitim kurumları arasında kurulan güçlü bağlarla ve eğitim kurumlarının sahip oldukları uygulama olanakları ile mümkün olmaktadır. Turizm sektörüne yönetici adaylarını yetiştiren üniversitelerde de uygulamalı eğitime gerekli özenin gösterilmesi gerekmektedir. Uygulamayı bilmeyen öğrencinin staja gönderilmesi hem okulun itibarını sarsmakta hem de öğrencinin en alt kademedeki işlerde görevlendirilmesiyle, stajın amacına ulaşmasını engelleyerek (Soybalı ve Bayraktaroğlu, 2013:187) öğrencilerin sektörden uzaklaşmasına neden olmaktadır (Emir vd., 2010). Bu bağlamda öğrencilere sektörde iyi pozisyonlarda istihdam edilmelerini sağlayacak yeterliliğin aktarılması bakımından uygulamalı eğitim ve bu eğitimi verenlerin uygulamalı bilgiye ve deneyime sahip olması önemlidir. Turizm bölümlerinde ortaya çıkan teorik bilgi ağırlıklı aşırı akademikleşme öğrencilerin sektör algılarını olumsuz yönde etkileyebilir.

Literatürde turizm öğrencilerinin sektör algıları ve çalışma niyetleri çok işlenen bir konudur. Fakat Stone ve diğerlerinin (2017) de belirttiği gibi öğrencilerin turizm sektörüne karşı algı ve tutumlarından ziyade sektör içerisindeki belirli bir alana karşı algı ve tutumlarının ölçülmesi önemlidir. Bu bağlamda bundan sonraki çalışmalarda öğrencilerin otel işletmelerine ve seyahat acentelerine karşı algıları ölçülebilir. Hatta daha da ayrıntılı olarak ön büro departmanına ve yiyecek içecek departmanına karşı algıları da karşılaştııılabilir. Bunun sonucunda oluşan olumsuz algının turizm sektörünün hangi biriminde yoğunlaştığı tespit edilebilir.

\section{KAYNAKÇA}

Ağaoğlu, O., K. (1991). Türkiye'de Turizm Eğitimi ve Etkinliği, Milli Prodüktivite Merkezi Yayınları 439, Ankara: Yeniçağ Basım Yayın San. Ltd. Şti.

Aksu, A. and Koksal C.D. (2005). Perceptions and Attitudes of Tourism Students in Turkey, International Journal of Contemporary Hospitality Management, 17(5): 436-447.

Aymankuy, Y. ve Aymankuy, Ş. (2013). Turizm İşletmeciliği Eğitimi Alan Öğrencilerin Turizm Sektöründeki İstihdamla İlgili Görüşleri ve Sektördeki Kariyer Beklentileri: Balıkesir Üniversitesi Turizm İşletmeciliği ve Otelcilik Yüksekokulu Örneği, Akademik Bakış Dergisi, (35): 1-21. 
Bayraktaroğlu, E. (2013). Türkiye'de Lisans Düzeyinde Turizm Eğitimi Veren Kurumların Uygulama Olanakları. (Yayınlanmamış Yüksek Lisans Tezi). Afyon Kocatepe Üniversitesi, Sosyal Bilimler Enstitüsü.

Boylu, Y. (2004). Anadolu Otelcilik ve Turizm Meslek Liselerinde Öğrenim Gören Öğrencilerin Okul Amacına Yönelik Beklentilerinin Değerlendirilmesi (Yayınlanmamış Doktora Tezi). Ankara: Gazi Üniversitesi Eğitim Bilimleri Enstitüsü.

Çakıcı, C. A. ve Özdamar, M. (2018). Üniversite Düzeyinde Turizm Eğitimi Alan Öğrencilerin Dışa Dönüklükleri ve Hizmet Yönelimlerine Göre Kümelendirilmesi, Türk Turizm Araştırmaları Dergisi, 2(2): 42-54.

Çinko, M., Yurtkoru, S. ve Durmuş, B. (2013). Sosyal Bilimlerde SPSS'le Veri Analizi. İstanbul: Beta Basım Evi.

Duman, T., Tepeci, M. ve Unur, K. (2006). Mersin'de Yükseköğretim ve Orta Öğretim Düzeyinde Turizm Eğitimi Almakta Olan Öğrencilerin Sektör Çalışma Koşullarını Algılamaları ve Sektörde Çalışma İsteklerinin Karşılaştırmalı Analizi, Anatolia: Turizm Araştırma Dergisi, 17(1): 51-59.

Emir, O. (2013). The Effect of Training on Vocational High School Students in Their Professional Development, Procedia - Social and Behavioral Sciences, 106(2013): 2724 - 2738.

Emir, O., Pelit, E. ve Arslan, S. (2010). Turizm Alanında Ön Lisans Eğitimi Alan Öğrencilerin Staj Öncesi ve Staj Sonrası Görüşlerinin Karşılaştırılması: Afyon Kocatepe Üniversitesi Örneği, Elektronik Sosyal Bilimler Dergisi, 9(33): 141-165.

Erdem, B., Akgöz, E. ve Gündoğdu, İ. (2018). Lisans Düzeyinde Turizm Eğitimi Alan Öğrencilerin Uluslararası Staj Deneyimlerine İlişkin Memnuniyet Algıları: Kırgızistan-Türkiye Manas Üniversitesi Örneği. Journal of Tourism and Gastronomy Studies, 6(2): 74-98.

Hacıŏlu, N. (1985). Turizm Eğitimi Yeterli mi?, Milliyet Gazetesi.

Işık, N., Pektaş, Ç. ve Atılgan, E. (2018) Turizm Ön Lisans Eğitiminde Kariyer Planlaması: Gaziantep Örneği. Türk Turizm Araştırmaları Dergisi, 2(2): 10-20. DOI: 10.26677/tutad.2018.28.

Kozak, M. A. ve Kızılırmak, İ. (2001). Türkiye'de Meslek Yüksekokulu Turizm-Otelcilik Programı Öğrencilerinin Turizm Sektörüne Yönelik Tutumlarının Demografik Değişkenlere Göre Değişimi: Anadolu, Akdeniz ve Karadeniz Teknik Üniversitesi Öğrencileri Üzerine Bir Uygulama, Anatolia: Turizm Araştırmaları Dergisi, (12): 9-16.

Kuşluvan, S., and Kuşluvan, Z. (2000). Perceptions and Attitudes of Undergraduate Tourism Students Towards Working in The Tourism Industry in Turkey. Tourism Management, 21(2000): 251-269.

Lu, T. Y. and Adler, H. (2009). Career Goals and Expectations of Hospitality and Tourism Students in China. Journal of Teaching in Travel \& Tourism, 9(1): 63-80, DOI: 10.1080/15313220903041972.

Mısırlı, İ. (2002). Turizm Sektöründe Meslek Standardı ve Mesleki Belgelendirme Sistemi, Anatolia Dergisi. 13(1): 39-55. 
ÖSYM (2017) 2017-ÖSYS Yerleştirme Sonuçlarına İlişkin Sayısal Bilgiler. Link;https://dokuman.osym.gov.tr/pdfdokuman/2017/OSYS/YER/YSay\%C4\%B1sal\%20Bilgiler1 5082017.pdf. Erişim, Mayıs, 2018.

Öztürk, Y. ve Pelit, E. (2008). “Turizm Alanında İşletmecilik ve Öğretmenlik Eğitimi Alan Öğrencilerin Kariyer Tercihleri Üzerine Bir Araştırma". III. Balıkesir Ulusal Turizm Kongresi, (353-360). Balıkesir: Balıkesir Üniversitesi Turizm İşletmeciliği ve Otelcilik Yüksekokulu.

Pelit, E. ve Güçer, E. (2006). Turizm Alanında Öğretmenlik Eğitimi Alan Öğrencilerin Turizm İşletmelerinde Yaptıkları Stajları Değerlendirmeleri Üzerine Bir Araştırma, Ticaret ve Turizm Eğitim Fakültesi Dergisi, (1): 139-168.

Richardson, S. (2008) Undergraduate Tourism and Hospitality Students Attitudes Toward a Career in the Industry: A Preliminary Investigation, Journal of Teaching in Travel $f \mathcal{E}$ Tourism, 8(1): 23-46, DOI: 10.1080/15313220802410112.

Richardson, S. (2009). Undergraduates' Perceptions of Tourism and Hospitality as a Career Choice, International Journal of Hospitality Management, 28(2009): 382-388.

Richardson, S. (2010). Tourism and Hospitality Students' Perceptions of a Career in The Industry: A Comparison of Domestic (Australian) Students and İnternational Students Studying İn Australia, Journal of Hospitality and Tourism Management, 17(2010): 1-11.

Richardson, S. and Thomas, N. J. (2012). Utilising Generation Y: United States Hospitality and Tourism Students' Perceptions of Careers in The Industry. Journal of Hospitality and Tourism Management, 19(2012): 1-13.

Soybalı, H. H. ve Bayraktaroğlu, E. (2013). Türkiye'de Lisans Düzeyinde Turizm Eğitimi Veren Kurumların Uygulama Olanaklarının Değerlendirilmesi Üzerine Bir Araştırma. Anatolia: Turizm Araştırmaları Dergisi, 24(2): 185-199.

Stone, M. J., Padron, T. C., Wray, M. L., La Lopa, J. and Olson, E. D. (2017). Career Desires and Expectations of Event Management Students. Journal of Hospitality and Tourism Management, 32(2017): 45-53.

Şahin, T. ve Arman, A. (2014). Ön Lisans Seviyesinde Aşçllık Eğitimini Tercih Etme Nedenlerinin Değerlendirilmesi. Akademik Bakış Dergisi, 41(2014).

Tabachnick and Fidell, (2013). Using Multivariate Statistics (sixth ed.) Pearson, Boston, 2013

Tuna M., Akça İ., Tuna A. A. ve Gürlek M. (2017). Turizm Öğrenimi Gören Öğrencilerin Sektör Çalışma Koşullarını Algılamaları ve Sektörde Çalışmaya Yönelik Tutumları: Meslek Yüksekokulu, Yüksekokul ve Fakülte Öğrencilerine Yönelik Bir Araştırma, Turizm Akademik Dergisi, 4(2): 41-60.

Türker, N., Uçar, M. ve Ateş, M. A. (2016). Turizm Eğitimi Alan Öğrencilerin Turizm Sektörü Algıları: Karabük Üniversitesi Öğrencileri Üzerine bir Araştırma. Karabük Üniversitesi Sosyal Bilimler Enstitüsü Dergisi, 6(2): 311-333.

UNWTO. (2017). UNWTO Tourism Highlights 2017 Edition. World Tourism Organization.

Ünlüönen, K. ve Boylu, Y. (2005). Türkiye'de Yükseköğretim Düzeyinde Turizm Eğitimindeki Gelişmelerin Değerlendirilmesi. Elektronik Sosyal Bilimler Dergisi, 3(12):11-32. 
Ünlüönen, K., Temizkan, R. ve Gharamaleki, M. R. E. (2010). Turizm İşletmeciliği Öğretmenlik Programlarının Öğrenci Beklentileri ve Algılamaları Açısından Karşılaştırılması (1998-1999, 2003-2004 ve 2008-2009 Öğretim Yılları). Ticaret ve Turizm Eğitim Fakültesi Dergisi, 2(2010).

WTTC. (2018a). The Economic Impact of Travel and Tourism (World). World Travel and Tourism Council.

WTTC. (2018b). The Economic Impact of Travel and Tourism (Turkey). World Travel and Tourism Council.

YÖK (2017). 2017 Lys Yerleştirme Analizi. Link; http://yok.gov.tr/documents/10279/35516479/YOK_2017_Lys_Yerlestirme_Analizi.pdf/. Erişim; Mayis, 2018. 